\title{
Philosophical expertise as a factor of desubjectivation of the technogenic trend and achievement of social justice
}

\author{
I. N. Tyapin, V.M.Maslov' \\ ${ }^{1}$ Vologda State University, \\ 15, ul. Lenina, Vologda, 160000, Russian Federation \\ 2 Lobachevsky State University of Nizhny Novgorod, \\ 23, pr. Gagarina, Nizhny Novgorod, 603022, Russian Federation
}

For citation: Tyapin I. N., Maslov V.M. Philosophical expertise as a factor of desubjectivation of the technogenic trend and achievement of social justice. Vestnik of Saint Petersburg University. Philosophy and Conflict Studies, 2019, vol. 35, issue 4, pp. 569-579. https://doi.org/10.21638/spbu17.2019.404

The article substantiates the idea for the establishment of philosophical expertise as an actual theoretical and practical form for solving the fateful problems of our time. The direct source of the philosophical expertise is humanitarian expertise, brought to life by the use of modern biotechnology. A working mechanism of dialogue of civil society, the scientific community with the government and business has formed. New spheres of reality have been designated where it was possible and necessary to involve humanitarian, social, examination. All positive achievements in the field of social and humanitarian expertise are enriched and generalized within the framework of philosophical expertise. Philosophical examination should indicate the main thing. Social justice is an integrated category that has social, moral, legal, and political (including geopolitical) significance. Problems of social justice should be seen as the focus of negative trends in capitalistic globalization. The technogenic trend - an increasingly accelerating process of spreading and developing everything related to the technical, technological in its corresponding uncertainty and increasing impact on social life, on the fate of humanity in the form of catastrophes, self-destruction, post-out-human overcoming - even stronger conserves and enhances social injustice. Philosophical expertise can contribute to the solution of global problems, changing the negative vector of the functional relationship of technogenic and social processes to the positive; the return of man, society, and the national state, of the role of subjectivity, in solving the issues of its further existence effectively.

Keywords: globalization, social justice, technogenic trend, NBICS-convergence, transhumanism, dehumanization, pseudo-rationality, humanitarian expertise, philosophical expertise.

The category of justice is one of the key categories both in ethics and in law. In the course of the integration of axiological components of ethical and legal normative systems, justice is transformed into the concept of social justice as a combination of action and compensation, rights, and obligations. Today, the risks and challenges to equity are becoming an inter-social problem. The existing cultures and civilizations, which defend their identity, differ significantly in the perception and understanding of values such as human rights, norms of morality and the ideal of social justice in the context of neo-liberal globalization. As a result, new internal and external threats and conflicts arise. In civilized societies, these ideals and norms are embodied primarily in the social obligations of the state [1, p. 126], without which their existence is almost impossible.

(c) Санкт-Петербургский государственный университет, 2019 
Westernized globalization is destroying state sovereignty and national identity, ultimately leading to conflicting results. Cultural achievements are widespread and more accessible. But there is also a decline in the level and quality of life of the majority in the interests of global minorities ('elected' countries, peoples, social groups). In today's information society, not everyone will have access to the benefits of life and social inequality will not only shift to it from previous eras, but increase [2, p. 115]. It is not surprising that in the system of social values and expectations of the modern Russian society, a society that resisted (albeit in a passive form) the implementation of the model of anarcho-capitalism, social justice is increasing occupying a significant position in the system of values and expectations. Reflecting public consciousness, philosophical criticism of westernized globalization focuses on the establishment of more just, equitable (in the future and ideally) relations between states. Quite naturally, such a desire is complemented by the requirement to establish equally fair relations within each country in terms of the maximum possible reduction of the gap in the level and quality of life of citizens.

Based on this, social obligations, social justice should not be seen as a mere collection of social services, benefits, subsidies and other benefits that the state provides to all its citizens or certain groups. Social justice is a system of regulators of socio-economic and socio-political processes in society, as well as spiritual and moral attitudes (principles) developed by society, expressed in the laws of the state and reflected in the consciousness of the person (citizen), acquired by him in the process of personal development.

Thus, justice is an integrated category having simultaneously social, moral, legal and political (including geopolitical) significance. In this regard, it can be argued that no national-state idea in Russia cannot be implemented without the support of the idea of social equality and justice. Social equality and justice as spiritual guidelines of the society are the basis for the implementation of any large-scale social project. Social justice as the most important foundation of any organization can be realized both in the generally accepted legal norms and in the moral and value context.

The 'integral' nature of social justice, in turn, clarifies and demands a lot. To solve various problems, modern society creates new regulatory structures in the form of expert communities. But it is impossible to achieve social justice solely within the framework of positive legislation of the so-called 'rule of law', as well as narrow expert professionalism of applied science. First, with such an approach, that is not systematic nor one-sides, there is no strategy for the development of society or individual institutions. Secondly, in practice, the right without morality turns into fiction, arbitrariness of the strong and the triumph of a pronounced class interest. Thirdly, the axiology of such an approach relies on arbitrarily interpreted freedom, which cannot be an absolute value.

At the same time, the lack of social justice and prospects for the majority realized in Russian society (and in most countries of the world community), the growing strengthening of social segregation is an integral part of an even more serious global problem - the emergence of a real threat to human existence as a species because of the needs of a technocratically oriented civilization. We can confidently speak about the 'technogenic trend,' defined as accelerating the process of dissemination and development of everything related to technical, technological in its corresponding uncertainty and increasing impact on social life, on the fate of humanity in the form of catastrophes, self-destruction, and post-out-human overcoming. The array of the technogenic in modern society leads to the 
obvious expansion of the territory of man-made, rational, and artificial due to natural and cultural $[3 ; 4]$.

The considerable manipulative potential technological trend is defined by both the technologies and their usage as an ideology. Within the framework of the first aspect, it is possible to state with confidence that the technogenic trend in its current form stimulates the process of transformation of a person into a controlled and fully controlled technological being. As part of the second aspect, it is correct to speak and criticize enthusiastic without-thoughts about NBICS-convergence, cryptocurrencies, the digital economy, and the like. These enthusiastic without-thoughts makes it possible to divert the attention of mankind from global problems and contradictions, to 'forget' about the growing technical and economic gap, economic, political, and cultural expansion of the super-developed countries as well as their exploitation of human resources and the Earth's natural resources. Based on this, enthusiastic without-thoughts are trying to completely displace from the system of fundamental values the following aspects: national and cultural identification, patriotism, caring for another, and the metaphysical search for the meaning of life.

Implementation of the process 'loss of humanity' is the process of consistent irreversible loss of the species Homo sapiens and their complex of spiritual, moral, intellectual, and social qualities that distinguish a person from the surrounding reality and make it a special sphere of existence. This process includes a range of particular areas. Among them the following stand out: motivated egocentric view of the world; cultivation of consumerism; contribution to the atrophy of the sense of shame by pornography and obstinate language and culture; discrediting and gradual elimination of the institution of the family; destruction of cultural sexual identity; the exaltation of the pseudo; the transformation of the entire industry of mass culture in promoting the positivity of cyborgization; dissemination of the technologies of total control over the actions and the transition to chipping; chimerization of an organism by genetic engineering; the dictates of manipulative technologies in social management; and inculcation of total cynicism, the rejection of higher values, taboos, and restrictions.

The justification of the 'naturalness' of 'loss of humanity' is carried out within the framework of the methodology of pseudo-rationality. This term implies the borrowing of the contents of parcels from an imaginary, syllogism, and separated from the experiences and values $[5$, p. 52] on the idea of V.S. Shvyrev - the alienation of the ideal designs from the fullness of real existence [6, p. 115] and conscious use of sophistry, and intellectual trickery, in the abuse of terminology [7]. According to the ideas of V.N. Porus as well as totalitarianism and conformism, and political irrationality - all these socially established cases of parasitism are due to the 'split of rationality' [6, p. 113].

Pseudo-rationality is not limited to a set of propagandist means for manipulating the mass consciousness (distortion, concealment and special ways of presenting information), as well as linguistic methods arising from the cultural context: euphemisms, stereotypes, ideologemes, and metaphors. It is also the methodological 'core' theoretical pseudoscience and post-philosophy.

In the field of social and humanitarian knowledge, the following phenomena are clear examples of pseudoscience, violation of the laws of logic and principles of interaction between empirical and theoretical, and "fitting" the facts under a limited set of dogmas: monetarism (coming from the false thesis of domination in the modern economic sphere of market self-regulation); right libertarianism in the theory of law (asserting that an ab- 
solutely formal interpretation of freedom, equality and justice is an abstraction of real order as if they existed in history, and interpreting the social obligations of the state as 'despotism'); the doctrine of gender (ignoring the physiological differences of the sexes, the predominant use of anomalous facts and phenomena to the detriment of the typical arbitrary assumptions like 'male chauvinism' of the language and folk culture, etc.).

'Post-philosophy' (more precisely 'pseudo-philosophy') acts as a forward indicator of cognitive ability in modern virtualized and desacralizing - man in the new space of 'beast-machine.' This implies a conscious rejection of holistic consideration in favor of focusing on the part, fragment, as well as a special style that is ironic, paradoxical, somewhat idiotic' [8, p. 10-11].

The trans- and post-human image of the future man as a mechanized part of the network or system with bionic implants, supporting the life and functioning of the organism post-rationality, is 'mounted' with the notion of infinite freedom and unlimited possibilities. But obviously, this opens up a new level of control over the mind, actions and vital activity of the individual in general. For such an individual, the absence of a technical part would literally be death-like (nullifying all optimistic claims of infinite freedom, ostensibly an opening up of the individual as a result of 'technological improvement'). Transhumanism is the target completion of postmodernism when the idea of immortality turns into the apologia of death. This is not today's individuals, but rather the generic man. M. Foucault, G.Deleuze, J.Derrida are 'virtuosos' of pseudo-rationality. They, 'juggling' the concept of 'freedom,' developed the famous idea of 'a body without organs' ('protoplasmic substance,' 'medium of intensities,' 'kinetic amoeba') - a shapeless unconstructed formation, some 'cleared place' for the application of signs or implantation of chips. The technology of transformation of humanity excludes the right of the individual to freedom and, consequently, justice within the framework of the social order.

A hypothetical solution for the crisis of man and society in their "traditional" form is conceivable only within the framework of a truly philosophical approach, philosophical expertise. The spread of philosophical expertise can eliminate the 'scissors', the gap between the lack of understanding a significant part of modern society and the role and importance of philosophy and its objectively life-saving potential. As noted by A. Gorina, philosophical (philosophical-anthropological, in the terminology of the author) expertise is 'the expertise of the whole culture and civilization, and the subject of philosophical anthropology becomes an expert when he feels, sees that humanity is dying. At the same time, the expert, as a rule, gives a critical assessment of what is happening in the world, offering humanity an expert opinion or a way of survival in conditions of evil... or a way of overcoming evil' [9, p. 116]. According to B. Yudin, new ethical and legal problems generated by modern scientific and technical achievements are interdisciplinary in nature. And it is from the standpoint of philosophy that one can see them in the widest possible perspective, while keeping them in focus and even rediscovering their various interdisciplinary aspects' $[10$, p. 81$]$. The subject of philosophical-anthropological expertise is qualitatively different from scientific expertise (despite the fact that the philosophical examination of itself is associated with the general scientific, its continuation). Besides those requirements which are imposed on the subject of scientific examination (professional competence, responsibility, etc.), one has to possess thinking of planetary scale.

The formulation of the problem of philosophical expertise is appropriate because the technogenic trend is rightfully considered to be one of the most large-scale, post- 
non-classical objects of research. Post-non-classical epistemology/rationality, on the one hand, is precautionary and restrictive. The initial value loading of the object, axiologically requires maximum transparency and evidence-based practice in its study. The complexity of the post-non-classical object of study results in the acceptance of the fundamental openness to the improvement and criticism of any result. On the other hand, post-nonclassical gnoseology - objectively removing the special importance of the analysis of simple, elementary aspects and conclusions - directly focuses on the study of such aspects of objects, where values (for example, interdisciplinary) and complexity (for example, the transition of quantity to quality) are quite clearly represented. This is directly correlated with the known performance: 'where there is danger, there is growth and salvation.'

Philosophical expertise is in many respects consonant with humanitarian expertise and objectively is a continuation of the latter, a generalization of its theory and practice.

Historically, humanitarian expertise originated in the bosom of biomedical ethics. The connection of humanitarian expertise with biomedical ethics is objective. Biomedical ethics first, is one of the longest-lasting ethical traditions dealing with the problem of professional man-made effects on a human (Hippocratic oath), and secondly, quite possibly, is now working on 'the field of the most radical transformations in man' [11, p. 24]. In the national tradition, the formation of the concept of humanitarian expertise is attributed to the activities of I. Frolov, I. Ashmarin and B. Yudin. Currently the problem of the interrelation of bioethics and humanitarian expertise is being developed at the Institute of philosophy of the Russian Academy of Sciences [12, p. 87, 92]. The quality and speed of modern man-made changes are required to appeal to a wide range of experts, professionals, people, to the entire scientific community and society as a whole [13, p. 120, 123-125], in the ideological field - to the utmost philosophical issues of being and knowledge. This objective request, on the one hand, involves the analysis of a wide range of existing ethical developments of modern scientific and technological development [14, p. 74-81], on the other hand, activates the trend towards harmonization of efforts and concepts. All this logically led to the need to form a new expert structure, namely, humanitarian (exploring modern man-made risks or general risks, an integral part of which are man-made, from the point of view of the person) expertise (based on a very wide, in principle, comprehensive range of human knowledge and interests). These two essential points are present in any modern definition of humanitarian expertise. For example, 'humanitarian expertise is a form of dialogue between civil society and the state on the permissibility or scale of the use of technologies that may pose a threat to human life and health, as well as on the applicability of various innovations' [2, p. 115].

The awareness of unity generated by the man-made humanitarian trend (the crisis of the human corporality and spirituality) and social problems (threatening social justice) directs humanitarian expertise in the direction of its more accurate and deeper understanding of philosophical expertise. Thus, opinions of domestic researchers can differ in questions of communication of philosophical (philosophical-anthropological, humanitarian) expertise with the classical status, the purposes and value attitudes of philosophy.

As a result, P. Tishchenko sees the purpose and methodology of humanitarian expertise as a continuous monitoring of problems, decisions and tracking the long-term consequences in 'clarifying the depth and paradoxical problems through multidisciplinary discussion' $[15$, p. 205]. The multidisciplinary approach proposed by him as a methodological basis, the participation of representatives of different social sciences in order to obtain a 
generalized picture of causation and possible negative consequences, would seem to imply a single value and worldview platform. However, this author antinomically articulates the plurality of value-ideological grounds in the modern era, and, accordingly, the plurality of moral assessments of a particular project or phenomenon (in particular, on the issue of human identity, in connection with advances in biotechnology and artificial intelligence).

V.Syrov considers the prospects of philosophical expertise as a set of 'informal' intellectual operations within the philosophical community, both the customer and the contractor, based on the irreversibility of the crisis of classical forms of philosophizing. The basis of philosophical expertise should be a reflexive attitude, and its object can be any products and forms of culture explicated in the form of discourses. The critical analysis of the latest philosophical competencies (methodological guidelines) can be transformed into normative guidelines or regulations related to the search for possible long-term consequences, which can lead to the implementation of proposed ideas (for example, how can the decisions taken in the field of economics affect the social, political, and cultural spheres). As for establishing their causes, the specificity of the philosophical approach convincingly demonstrates that these lay not in the 'malice of individual actors' or 'technical errors,' but in the character of the chosen principles ('the power of discourses'). In other words, 'the philosopher must display the will to reject any projects, ideas, beliefs in any of their technical sophistication and good faith performance due to the rigidity of the framework, which are set by the accepted prerequisites. So, for example, when a well-known thinker wrote that on the grounds of strictly logical character it is impossible to predict the course of events, and therefore certain types of social theories are impossible, he realized the type of criticism described to us' [16, p. 134].

A. Gorina noted that the expansion of understanding philosophical expertise on how the context and main goal contemporary philosophical research is repelled not from postmodern installations, but from classical understanding of the philosophical functions. She identifies the methodological foundations for understanding the meaning and purpose of philosophical expertise of dialectical analysis: the principles of integrity, complementarity and consistency, the unity of scientific and philosophical methods. The author distinguishes the following specific features of such examination: 1) not a situational character; 2) the lack of an approved status of procedures and findings; 3 ) lack of contracting expertise, whose role is played by the 'challenges' of history itself, 'answers' which in turn are philosophical theories, models, utopia - expert opinions; 4) significant temporal length - from several years to several centuries and longer); 5) great deliberateness, extended to all mankind, not individual communities and groups; 6) a special topology, spatial-temporal conditions (some seminars, conferences, etc.); 7) representation of results in the form of scientific and literary texts; 8) the widespread availability and openness to participation [17].

Also of interest, as a result of A. V. Gorina's work, are three varieties of philosophical expertise. Rational expertise (where the 'expert-specialist') is an expertise based on scientific methods, the conclusions which are logically and empirically supported. Irrational expertise (where the expert is an 'expert-critic') is an expertise based on a critical view of a person and culture. This position is close to antiscience. Here, the artistic vision of the world prevails, accompanied by the active use of images or metaphors (according to the authors of the article, such an examination is easy metamorphose to pseudo-rationality). The transcendentalist expertise (where the expert is an expert-savior) is an examination 
expertise that offers the world a strategy for saving humanity as a response to the challenges of man-made disasters.

A fundamentally different approach has been formulated by V. Kortunov and V.Skeleta. They propose the possibility of socio-humanitarian assessment of political processes in the framework of socio-humanitarian expertise. The basis of this expertise are the principles of humanitarian assessment, based on an objective ontological understanding of morality in the context of the phenomenon of archetypes, transcultural and super-individual matrices, models of thinking, meanings, values, and cultural images that regulate the activity of consciousness. This humanitarian assessment can be a specific and necessary alternative to legal expertise. Reliance on legislation to assess the socio-political processes initiated by the authorities is not always grounded on the humanitarian values on which human culture/civilization is based [18, p. 10].

The difference of ideas about the direction, value and methodological grounds, and the nature of philosophical expertise does not negate the fact that almost all the authors proceed from the understanding of philosophical expertise as an examination of a complex, long-term, prognostic, project, involving scenario analysis of the future, different from the 'narrow-special examination,' but at the same time dialectically related to it. It is common to understand philosophical expertise as an expertise devoted to the most urgent threats and risks facing a person, society and civilization, based on the unity of methodology and axiology acting as a socio-cultural technology. It is assumed that the spread of philosophical expertise will contribute to a new flourishing of philosophy, a significant increase in its status in the system of modern knowledge. It is important to fully take into account the current information and communication realities. Philosophical expertise like any phenomenon striving for a worthy realization should be an example in the use of modern information and communication technologies, in particular, for the dissemination of positive self-knowledge.

As part of the synthesis of existing developments, the authors do not accept provisions for the extremely broad interpretation of philosophical expertise. In practice, this will lead to the erosion of its features. One should not insist on the informal status of philosophical expertise. In the conditions of domination in the modern world of mass culture and manipulative technologies of social management, the lack of special efforts and building the necessary infrastructure will not have any real consequences. The solution to the problem is likely to be a two-part process. The free philosophical creativity of thinkers-representatives of different views and directions engaged in understanding threats and risks have serious theoretical achievements (expressed in the form of dissertations, monographs, publications in high-rating publications), and their work should be included in the official expert bodies (or even the creation of special philosophical expert bodies). This should save society from simplified interpretations and stamps dominating in relation to this or that topic, illustrate the ambiguity of the problem, and provide the administrative institutions a system of coordinates for self-determination in relation to the decisions taken. The results of the work of philosophical expert bodies in this case are both normative (within the framework of international and national laws, ethical codes of professional communities, etc.) and informal (within the limits of the influence that the expert body has on public opinion).

In determining the range of problems that form the areas and activities of philosophical expert bodies, it is necessary to proceed from the relationship of the national and 
universal. The idea of world civilization should be an expression of the tendencies of local civilizations towards universalization, and the idea of local civilization should reveal the structure of world civilization in terms of expanding the possibilities of its evolution. In this case, global problems transform into threats to national security, reproduction and the quality of life of the population, and political and spiritual sovereignty. The problem of the social ideal becomes the search for and realization of the ideal of the national-cultural.

Philosophical expert practice should be as attentive as possible to the problem of its axiological foundations and ideals. The extension of adequate modern challenges of values will provide a philosophical expertise of fundamental success. The 'blurred' social ideal and misunderstanding of the significance of civilizational uniqueness (due to the value split between the scientific and philosophical community), 'embryonic' of the nationalstate idea and the strategy of civilizational development is directly related to such a feature of most works on philosophical expert activity as the absence of specific parameters of philosophical expertise also known as expert evaluation criteria. The desired set of criteria can be identified within the framework of the social ideal, to which (sub)consciously the majority of Russian society gravitates. The core element is social justice as ensuring the distribution of positive rights and benefits in accordance with the real merits to society for the purpose of enabling a balanced functioning and development of society-family and the state of justice, capable of adequate responses to all the 'challenges' of time. According to the authors of this article, such criteria should include the following: the main list of ethical virtues, the balance of rights and obligations (each new right generates duty and self-restraint), ensuring real equality of opportunity, humanistic ideal (contributing to the comprehensive moral, intellectual, and physical - development of each citizen), and social solidarity (prevention of atomization).

Philosophical expertise unfolds during the direct correlation of a man-made trend with globalization. Humanitarian assessments relate to practical action for social justice. This implies and requires interlinked and mutually reinforcing trends: formal and informal, individual and collective. In principle, a philosophical examination can be conducted by a person who has the relevant knowledge and the ability to critically consider the generalization of results. However, normally it is the joint activity of many people within a certain structure/organization or spontaneously arising and self-organizing activity of ethically responsible thinkers.

The original value of philosophical expertise is that it appeals to reason (including, collective), the self-esteem of people who should not be slaves to technology, slaves living in consumer worship of it, as well as the eternal fear that technology will do something (or has already done) to them. The implementation of philosophical expertise is a mandatory stage and a condition for the legalization of administrative decisions relating to the main areas of social and humanitarian life. Philosophical expertise is a crucial tool for overcoming the mind of the government and societal rule of technological determinism, based on the idea of the absolutely immanent logic of technological progress that fully defines social development without the will of man, as well as the willingness to capitulate to the global dehumanization. The fundamental guiding value of philosophical expertise is related to its focus on depriving the technogenic trend of the status as the main subject of social and humanitarian evolution. The final goal of the philosophical examination is to provide public leadership an understanding of what is happening in the field of technogenic reality in order to transform it into an instrument of social justice in the state and the world. 
Accordingly, all the characteristic components of the technogenic trend are the subject of philosophical and expert consideration and criticism. For example, naturally follows the general criticism of the high rate of scientific and technical changes, and a reasonable agreement with the idea of a kind of 'presumption of guilt' of serious quality innovations.

Positive ideas and practices that form the basis of the movement and the very reality of the new social life must be developed within the framework of philosophical examination. Examples of the qualities required here are environmental ideas, the concept of reverence for the life of A.Schweitzer, the ideas of the ancient Eastern philosophy [19, p. 676-697], and in general all ideas pertaining to the paramount importance of spiritual and cultural development. Activity in line with the concept of 'small - fine' promotes activities that do not go beyond the possibilities of human muscles [20, p. 43]. This kind of activity can serve as one of the positive examples of reorientation (can be said, a certain sublimation) recognizable to us as large-scale (great) technogenic activity in a quite acceptable form for the general safety of society.

The realization of philosophical expertise turns the philosophical community from an object of manipulation, a tool for servicing ideologies and questionable paradigm attitudes into a full-fledged subject of social management at the local and global levels. This makes the philosopher uphold a standard of citizenship as a moral duty and responsibility to their own national-state community and humanity, a willingness to defend and protect their rights and interests. Philosophical expertise, forming the basis of rational choice between different options, returns to socio-humanitarian knowledge and management of a truly systematic approach. Accordingly, the philosophical examination allows for the interpretation of information and social processes adequately, preventing the leveling of moral attitudes and principles, to overcome the permanent social instability leading to the degradation of system-forming social institutions. Also, philosophical examination preserves the sovereign political and civilizational formations to ensure multipolarity of the future world civilization.

The course of implementation of the ideas of social justice should be accompanied by a certain decrease in investment in the latest, most complex (bordering on dangerous) man-made projects due to the reduction in the sources of exploitation in dependent countries for global governance entities (formerly known as the 'Golden billion'). Therefore, the quest for social justice, by definition, affects the interests of all. The proximity of philosophical expertise to the theory and practice of social justice allows us to hope that this expertise will reflect the majority. Accordingly, it is possible to assume the possibility of productive philosophical and expert work to solve global problems and returning the role of subjectivity to man, society, and the nation state in resolving the issues of its further existence.

\section{References}

1. Leksin, V. N. (2008), “Social justice as a norm”, Kontury global'nykh transformatsii: politika, ekonomika, pravo, no. 6, pp. $125-136$.

2. Lukov, V.A. (2012), "From social expertise to humanitarian expertise", Znanie. Ponimanie. Umenie, no. 2, pp. 114-118.

3. Kutyrev, V. A. (1994), Natural and artificial: the struggle of the worlds, Nizhnii Novgorod Publ., Nizhnii Novgorod. (In Russian)

4. Simon, H. (2004), The sciences of the artifical, rus. ed., trans. by Nappel'baum, E. L., Editorial URSS Publ., Moscow. (In Russian) 
5. Castoriadis, C. (2003), The imaginary establishment of society, rus. ed., trans. by Volkova G., Gnozis: Logs Publ., Moscow. (In Russian)

6. Lektorskii, V. A. (ed.) (1995), Historical types of rationality, vol. 1, IF RAN Publ., Moscow. (In Russian)

7. Briekmont, J. and Sokal, A. D. (2002), The Intellectual tricks. Criticism of modern postmodern philosophy, Rus. ed., trans. by Kostikova, A. and Kralechkin, D., Dom intellektual'noi knigi Publ., Moscow. (In Russian)

8. Dugin, A. G. (2009), Post-philosophy. Three paradigms in the history of thought, MGU Publ., Moscow. (In Russian)

9. Gorina, A. V. (2011), "Scientific and philosophical-anthropological expertise: identity and differences”, Omskii nauchnyi vestnik, no. 5 (101), pp. 115-118.

10. Pronin, M. A., Yudin, B. G. and Sineokaia, Yu. V. (2017), “Philosophy as expert examination”, Filosofskii zhurnal, vol. 10, no. 2, pp. 79-96.

11. Tishchenko, P.D. (2009), "Human construction as re-de-con-struction", Konstruirovanie cheloveka: sbornik trudov III Vserossiiskoi nauchnoi konferentsii s mezhdunarodnym uchastiem, Tomskogo politekhnicheskogo universiteta Publ., Tomsk, pp. 24-28. (In Russian)

12. Voronin, A.A. (2013), "Humanitarian expertise: research experience and problems", Bioetika i gumanitarnaia ekspertiza, vol. 7, pp. 87-112.

13. Bekhmann, G. and Gorohov, V.G. (2012), "Socio-philosophical and methodological problems of handling technological risks in modern society", Voprosy filosofii, no. 7, pp. 120-139.

14. Mitchem, C. (1995), What is the philosophy of technology?, rus. ed., trans. by Gorohov, V. G., Aspekt Press Publ., Moscow. (In Russian)

15. Tishchenko, P.D. (2008), "Philosophical grounds of humanitarian expertise", Znanie. Ponimanie. Umenie, no. 3, pp. 198-205.

16. Syrov, V.N. (2013), "Philosophical expertise: from metaphor to concept", Filosofskoe obrazovanie: Vestnik Assotsiatsii filosofskikh fakul'tetov i otdelenii, vol. 1 (4), pp. 125-137.

17. Gorina, A. V. (2012), "Philosophical-anthropological examination of how socio-cultural technology”, Abstract of Ph.D. dissertation, Omsk state pedagogical University, Omsk. (In Russian)

18. Kortunov, V. V. and Shkeleta, V.O. (2014), "To the question of philosophical and cultural justification of humanitarian examination of socio-political processes", Servis PLUS, vol. 8, no. 4, pp. 9-14.

19. Stepin, V.S. (2003), Theoretical knowledge, Progress-TraditsiiaPubl., Moscow, Russia. (In Russian)

20. Rapp, F. (1989), "Philosophy of technology: review", in Arzakanyan, C. G. and Gorohov, V. G. (ed.), Filosofiia tekhniki v FRG, Progress, Moscow, pp. 24-53.

Received: January 7, 2019

Accepted: June 13, 2019

Authors'information:

Igor N. Tyapin - Dr. Sci. in Philosophy, Associate Professor; tyapinigor@mail.ru

Vadim M. Maslov — Dr. Sci. in Philosophy, Professor; maclov@bk.ru

\section{Философская экспертиза как фактор десубъективации техногенного тренда и достижения социальной справедливости}

\section{И. Н. Тяпин ${ }^{1}$, В. М. Маслов ${ }^{2}$}

${ }^{1}$ Вологодский государственный университет, Российская Федерация, 160000, Вологда, ул. Ленина, 15

${ }^{2}$ Нижегородский государственный университет им. Н.И. Лобачевского, Российская Федерация, 603022, Нижний Новгород, пр. Гагарина, 23

Для цитирования: Tyapin I. N., Maslov V.M. Philosophical expertise as a factor of desubjectivation of the technogenic trend and achievement of social justice // Вестник Санкт-Петербургского университета. Философия и конфликтология. 2019. Т. 35. Вып. 4. С. 569-579.

https://doi.org/10.21638/spbu17.2019.404

В статье обосновывается идея становления философской экспертизы как актуальной теоретико-практической формы решения судьбоносных проблем современности. 
Непосредственным истоком и примером философской экспертизы является гуманитарная экспертиза, вызванная к жизни достижениями и угрозами применения современных биотехнологий. Сложность проблем требовала обращения к различным специалистам и обычным людям. Сложился рабочий механизм диалога гражданского общества, научного сообщества с властью и бизнесом. Обозначались все новые сферы действительности, где можно и нужно было задействовать гуманитарную, социальную экспертизу. Все положительные достижения в области социальной, гуманитарной экспертизы обогащаются и обобщаются в рамках философской экспертизы. Философская экспертиза как новое качественное образование должна указать главное. Справедливость - интегрированная категория, имеющая одновременно социальное, нравственное, правовое и политическое (в том числе геополитическое) значение. Проблемы в области социальной справедливости следует считать фокусом негативных тенденций капиталистической глобализации, разрушающей государственный суверенитет и национальную идентичность. Техногенный тренд - ускоряющийся процесс распространения и развития всего связанного с техническим, технологическим в его соответствующей неопределенности и увеличивающемся влиянии на социальную жизнь, на судьбу человечества в форме катастроф, самоуничтожения, пост-вне-человеческого преодоления - еще сильнее консервирует и усиливает социальную несправедливость. Значительный манипулятивный потенциал техногенного тренда заключается как в самих технологиях, так и в оперировании ими как идеологией. Рассматриваются перспективы продуктивной философско-экспертной работы по решению глобальных проблем, смене негативного вектора функциональной взаимосвязи техногенных и социальных процессов на позитивный; по возвращению человеку, обществу и национальному государству роли субъектности в решении вопросов своего дальнейшего бытия.

Ключевые слова: глобализация, социальная справедливость, техногенный тренд, NBICS-конвергенция, трансгуманизм, расчеловечивание, псевдорациональность, гуманитарная экспертиза, философская экспертиза.

Статья поступила в редакцию 7 января 2019 г.; рекомендована в печать 13 июня 2019 г.

Контактная информация:

Тяпин Игорь Никифорович - д-р филос. наук, доц.; tyapinigor@mail.ru Маслов Вадим Михайлович - д-р филос. наук, доц.; maclov@bk.ru 